\title{
ДОСЛІДЖЕННЯ ХАРАКТЕРИСТИК МАКСИМАЛЬНОГО СТОКУ ВЕСНЯНОГО ВОДОПІЛЛЯ РІЧОК ПРИЧОРНОМОРСЬКОЇ НИЗОВИНИ
}

\author{
Шакірзанова Ж. Р., Смельянова К. Б.
}

\section{ВСТУП}

Територія Причорноморської низовини є неоднорідною у фізикогеографічному аспекті та простягається широкою смугою вздовж узбережжя Чорного та Азовського морів між дельтою Дунаю на заході і річками Приазов'я на південному сході ${ }^{1}$.

Сучасна низовина розташована в межах Причорноморської западини, яка ще в палеогеновому та неогеновому періодах внаслідок тектонічних зсувів неодноразово затоплювалась морем. Такі процеси вплинули на характер осадових відкладень, які покривають поверхню низовини, а саме вапняки, глини й піски, покриті потужним шаром лесу. Це створює умови для формування рівнинного рельєфу, який часто порушується замкненими пониженнями, а саме блюдцями $\mathrm{i}$ подами, а також річковими долинами й лиманами ${ }^{2}$. За характером рослинного покриву Причорноморська низовина виділяється пануванням трав'янистої степової рослинності, яка переводить поверхневий стік у грунтовий, затримуючи незначну частину опадів на своїй поверхні.

Річки розглянутої території протікають у степовій географічній зоні, яка характеризується посушливим кліматом, несталим зимовим режимом із нестійким сніговим покривом у зв'язку з частими відлигами, що приводять до часткового або повного танення снігу i формування зимових паводків різної інтенсивності та водності.

Однак у гідрологічному режимі річок Причорноморської низовини весняне водопілля належить до характерної багатоводної фази, об'єми стоку якого на невеликих річках півдня сягають $60-70 \%$ від річного i

\footnotetext{
${ }^{1}$ Физико-географическое районирование Украинской УССР. Киев : изд-во КГУ, 1968. $683 \mathrm{c}$.

2 Ресурсы поверхностных вод СССР. Т. 6 : Украина и Молдавия. Вып. 1 : Западная Украина и Молдавия / под ред. М.С. Каганера. Ленинград : Гидрометеоиздат, 1969. 884 с.
} 
формують основний річний стік у річці ${ }^{3}$. Весняне водопілля супроводжується підйомом рівнів води, виходом їі на заплаву, що у багатоводні роки призводить до затоплень територій, пошкодження та руйнації об'єктів і споруд господарської власності.

На території Причорноморської низовини виділено із дотриманням вимог Водної Рамкової Директиви СС 2000/60/СС ${ }^{4}$ річки за басейновим принципом, а саме річки Причорномор'я, річку Південний Буг, річки Приазов'я, річки суббасейну Нижнього Дніпра та Нижнього Дунаю ${ }^{5,6}$, які є об'єктом дослідження.

Метою роботи $€$ просторо-часовий аналіз характеристик максимального стоку весняного водопілля річок Причорноморської низовини під час статистичного оброблення, дослідження багаторічних тенденцій змін та однорідності часових рядів стокових величин та їх узагальнень по досліджуваній території.

Bихідні дані. Задля просторо-часового аналізу гідрометеорологічних характеристик річок Причорноморської низовини залучено дані спостережень за стоковими характеристиками (шарами стоку та максимальними витратами води).

Картосхема розташування гідрологічних постів на території Причорноморської низовини представлена на рис. 1. Діапазон водозбірних площ річок Причорноморської низовини охоплює басейни за розміром від $145 \mathrm{~km}^{2}$ (р. Кодима - с. Обжила) до $46200 \mathrm{kм}^{2}$ (р. Південний Буг - смт Олександрівка).

3 Гребінь В.В. Сучасний водний режим річок України (ландшафтногідрологічний аналіз). Київ : Ніка-Центр, 2010. 316 с.

${ }^{4}$ Водна Рамкова Директива Європейського Союзу 2000/60/ЄС. Основні терміни та їх визначення. Київ, 2006. 240 с.

${ }^{5}$ Гребінь В.В., Яцюк М.В., Чунарьов О.В. Гідрографічне районування території України як передумова розробки планів інтегрованого управління річковими басейнами. Гідрологія, гідрохімія і гідроекологія. 2012. Т. 2 (27). С. 8-16.

6 Методики гідрографічного та водогосподарського районування території України відповідно до вимог Водної Рамкової Директиви Європейського Союзу / В.В. Гребінь, В.Б. Мокін, В.А. Сташук, В.К. Хільчевський, М.В. Яцюк, О.В. Чунарьов, Є.М. Крижановський, В.С. Бабчук, О.С. Ярошевич. Київ : Інтерпрес ЛТД, 2013. 55 с. 


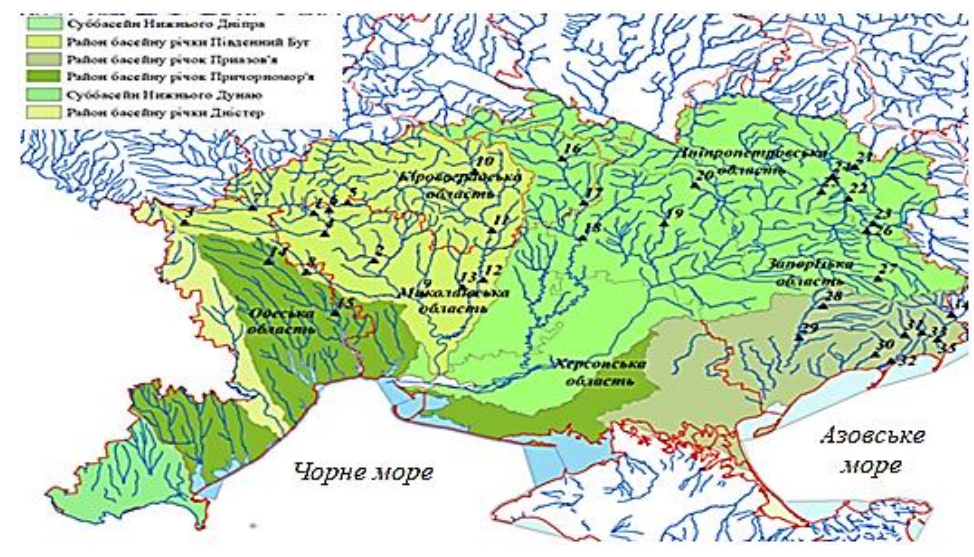

Рис. 1. Картосхема розташування гідрологічних постів на території Причорноморської низовини

Важливим показником гідрологічної вивченості території $\epsilon$ тривалість стокових спостережень на річках, яка змінюється в діапазоні від 18 (р. Вовча - смт Покровське) до 102 років (р. Південний Буг смт Олександрівка). Загалом на досліджуваній території 22 пости (63\% від загальної кількості) мають тривалі ряди спостережень, а саме більше 50 років; на 11 постах (21\%) гідрологічні ряди також достатньо тривалі й становлять $30-50$ років (табл. 1). Ряди тривалістю 11-30 років $\epsilon$ на 2 гідрологічних постах (6\%).

Таблиця 1

Розподіл водозборів за тривалістю стокових спостережень і величиною їх площ на річках у період весняного водопілля (станом на 2015 рік)

\begin{tabular}{cccccccc}
\hline \multirow{2}{*}{$\begin{array}{c}\text { Площа водозбору, } \\
\text { км }^{2}\end{array}$} & \multicolumn{7}{c}{ Кількість гідрологічних постів } \\
\cline { 2 - 8 } & $\mathbf{1 1 - 2 0}$ & $\mathbf{2 1 - 3 0}$ & $\mathbf{3 1 - 4 0}$ & $\mathbf{4 1 - 5 0}$ & $>\mathbf{5 0}$ & Всього & \% \\
$101-1000$ & & 1 & 4 & 2 & 7 & 14 & 40 \\
$1001-5000$ & 1 & & 1 & 4 & 9 & 14 & 40 \\
5 001-10 000 & & & & & 2 & 3 & 8 \\
$10001-20000$ & & & & & 2 & 2 & 6 \\
20 001-50 000 & 1 & 1 & 5 & 6 & 22 & 35 & 100 \\
Всього & 3 & 3 & 14 & 17 & 63 & 100 & \\
\% & & & & & 2 & 2 & 6 \\
\hline
\end{tabular}


Територія $€$ недостатньо невивченою у гідрологічному аспекті. Хоча пости на басейні мають тривалі часові ряди стокових спостережень, проте вони досить не рівномірно розміщені по території (рис. 1) і зазвичай не відповідають рекомендаціям Всесвітньої метеорологічної організаціїㄱ, згідно 3 яким для річкових водозборів, розташованих у межах внутрішніх рівнинних територій, мінімальна щільність гідрометричних постів повинна становити один пост на

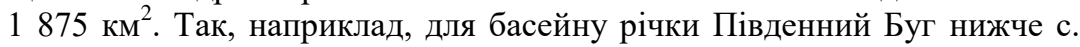
Олександрівка до гирла один пост із вимірювання витрат води припадає приблизно на 2900 км² $^{2}$

Так, найбільша кількість гідрологічних постів (80\% від загального їх числа) мають величини площ водозборів річок у діапазоні до

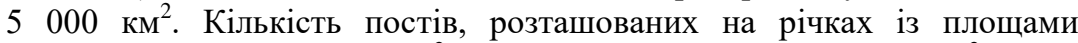
водозборів 5 001-10 $000 \mathrm{kм}^{2}$, становить 8\%, 10 001-20 $000 \mathrm{\kappa м}^{2}-6 \%$, а 3 площами більше 20000 км$^{2}-6 \%$ (табл. 1).

На досліджуваній території нараховуються 69 агро- та метеорологічних станцій із тривалістю спостережень, яка змінюється в діапазоні від 10 (ст. Мирнопілля) до 120 років (ст. Миколаїв). Як видно 3 табл. 2, кількість років спостережень $\leq 10$ та 11-20 невелика: їх частина становить лише $2 \%$ та $6 \%$ відповідно. Найбільшу кількість метеорологічних станцій (42\% від загальної їх кількості) мають ряди спостережень у діапазоні від 31 до 40 років. Період спостережень у діапазоні від 41 до $\geq 50$ років складає $28 \%$, а від 21 до 30 років - $22 \%$.

Таблиця 2

Розподіл метеорологічних станцій за тривалістю спостережень

Кількість метеорологічних станцій 3 періодом спостережень

\begin{tabular}{cccccccc}
$\leq 10$ & $11-20$ & $21-30$ & $31-40$ & $41-50$ & $\geq 50$ & Всього & $\%$ \\
1 & 4 & 15 & 29 & 6 & 14 & 69 & 100 \\
$2 \%$ & $6 \%$ & $22 \%$ & $42 \%$ & $8 \%$ & $20 \%$ & 100 & \\
\hline
\end{tabular}

\section{1. Дослідження часових тенденцій гідрометеорологічних} характеристик в умовах сучасних кліматичних змін

Для дослідження гідрологічних характеристик максимальних витрат води та шарів стоку весняного водопілля на досліджуваній території побудовані хронологічні графіки зв'язку $Y_{m}=f(t)$ і $Q_{m}=f(t)$, за допомогою яких можна встановити характер і тенденції у багаторічних коливаннях шарів стоку і максимальних витрат води водопіль.

${ }^{7}$ World Meteorological Organization. Guide to Hydrological Practices, Fifth Edition, TD No. 168, 1994. 
Для дослідження гідрологічних характеристик використані багаторічні дані за максимальними витратами та шарами стоку весняного водопілля. Побудовані хронологічні графіки гідрологічних характеристик весняного водопілля в басейні річок Причорномор'я показують зменшення досліджуваних величин як для максимальних витрат води (рис. 2), так і для шарів стоку весняних водопіль (рис. 3).

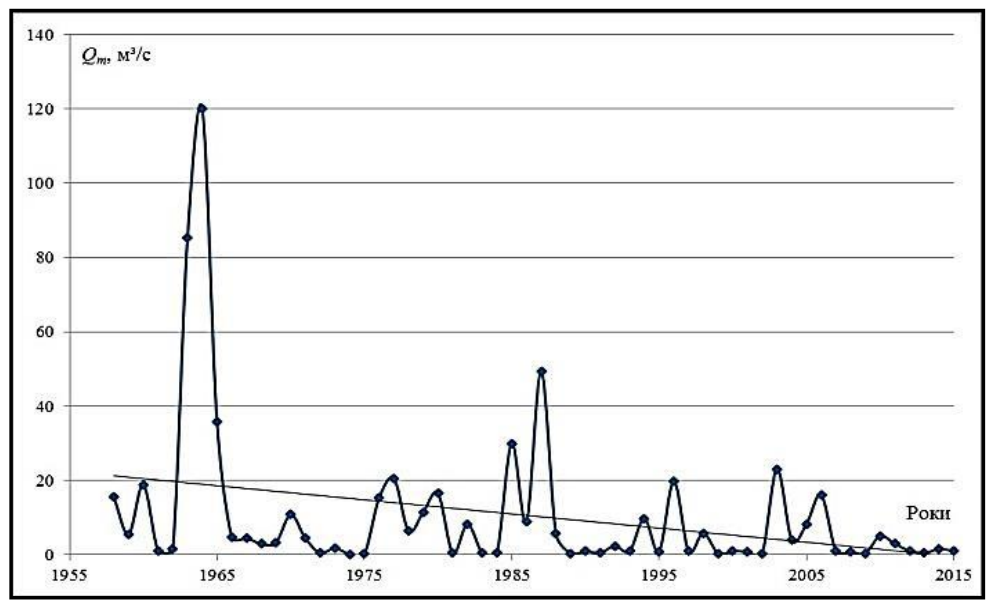

Рис. 2. Хронологічний графік ходу максимальних витрат весняного водопілля р. Мала Терса - с. Троїцьке, $\mathrm{F}=450$ км² $^{2}$

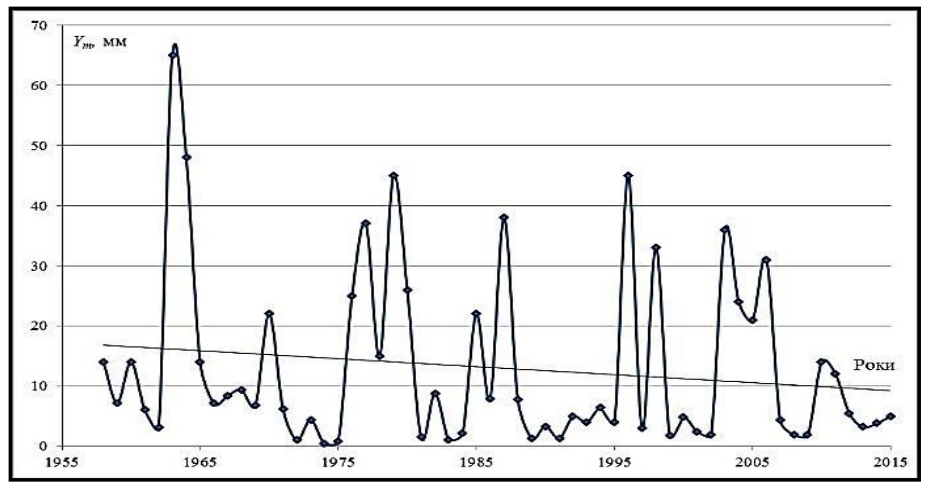

Рис. 3. Хронологічний графік ходу шарів стоку весняного водопілля р. Мала Терса - с. Троїцьке, $F=450$ км$^{2}$ 
Для максимальних витрат води та шарів стоку весняного водопілля визначено значимість лінійних трендів, які досліджені за критерієм $r>2 \sigma_{r}$, де $\sigma_{r}=\frac{1-r^{2}}{\sqrt{n-1}}-$ середня квадратична похибка розрахунку коефіцієнта кореляції, $n$ - число років спостережень ${ }^{8,9}$.

На прикладі р. Мала Терса - с. Троїцьке з рядом спостережень за гідрологічними характеристиками весняного водопілля $n=58$ рік спостерігається тенденція до суттєвого зменшення досліджуваних величин зі значущим $(r=0,32)$ для максимальних витрат води та 3 незначущим $(r=0,15)$ для шарів стоку весняного водопілля коефіцієнтами кореляції ${ }^{10}$.

За оцінкою значимості трендів за максимальними витратами води весняного водопілля отримано такі результати. Із 35 рядів тренд значущий у 18 рядів, а незначимий - у 16 рядів.

В графічному вигляді представлені області незначущих трендів часових рядів максимальних витрат води весняного водопілля на території Причорноморської низовини (рис. 4).

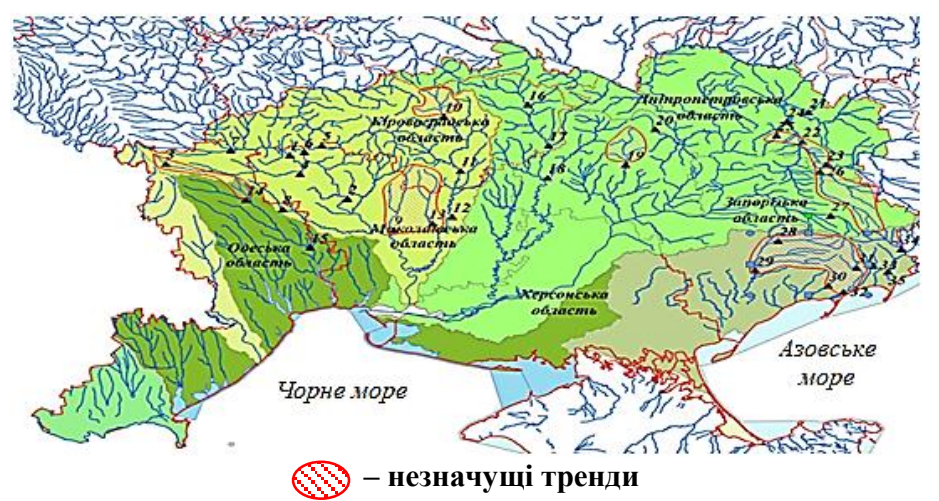

Рис. 4. Область незначущих трендів часових рядів максимальних витрат води на території Причорноморської низовини

8 Методические рекомендации по оценке однородности гидрологических характеристик и определению их расчетных значений по неоднородным данным. Санкт-Петербург, 2010. 162 с.

9 Рождественский А.В. Оценка точности кривых распределения гидрологических характеристик. Ленинград : Гидрометеоиздат, 1977. 260 с.

10 Смельянова К.Б., Докус А.О. Дослідження часових рядів характеристик весняного стоку річок території Причорноморської низовини. Екологія, неоекологія, охорона навколишнього середовища та збалансоване природокористування : матеріали VIII Міжнародної наукової конференції молодих вчених (26-27 листопада 2020 року, м. Харків). Комп'ютерне верстання: Баскакова Л.В., 2020. 
Аналізуючи області незначущих трендів максимальних витрат води весняного водопілля, отримаємо, що з 16 рядів 3 незначущим трендом неоднорідними є такі:

- за критерієм Фішера на рівні значущості 1\% неоднорідними є 7 рядів, на рівні значущості 5\% - 9 рядів;

- за критерієм Стьюдента на рівні значущості 1\% неоднорідними є 3 ряди, на рівні значущості 5\% - 4 ряди;

- за критерієм Вілкоксона на рівні значущості 1\% неоднорідними $€ 5$ рядів, на рівні значущості $5 \%-8$ рядів.

За шарами стоку отримано такі результати. 335 рядів тренд значимий у 13 рядів, а незначущий - у 22 рядів. У графічному вигляді представлені області незначущих трендів часових рядів шарів стоку весняного водопілля на території Причорноморської низовини на рис. 5.
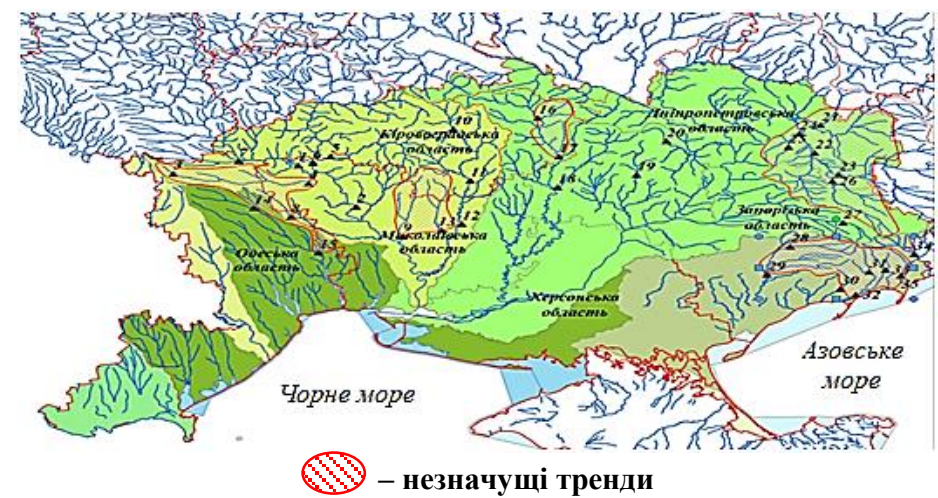

Рис. 5. Область незначущих трендів часових рядів шарів стоку весняного водопілля на території Причорноморської низовини

Аналізуючи області незначущих трендів шарів стоку весняного водопілля, отримаємо, що 322 рядів 3 незначущим трендом неоднорідними $є$ такі:

- за критерієм Фішера на рівні значущості $1 \%$ неоднорідними є 10 рядів, на рівні значущості 5\% - 13 рядів;

- за критерієм Стьюдента на рівні значущості 1\% неоднорідними є 2 ряди, на рівні значущості 5\% - 2 ряди;

- за критерієм Вілкоксона на рівні значущості $1 \%$ неоднорідними є 2 ряди, на рівні значущості $5 \%$ - 4 ряди.

Неоднорідність рядів може бути викликана умовами формування характеристик річкового стоку, на які впливають метеорологічні чинники. Зокрема, 3 початку $70-\mathrm{x}$ років минулого століття спостерігається підвищений стік зимової межені, як правило, за 
рахунок зменшення стоку весняної повені, тобто відбулася зміна внутрішньорічного розподілу стоку у зв'язку 3 підвищенням температур у зимовий період. Також на неоднорідність впливають природні чинники підстильної поверхні, регулювання річкового стоку, господарська діяльність, антропогенні чинники на водозборах річок. Ці та інші приклади можливих причин неоднорідності вихідної інформації щодо стоку наводить у своїй роботі А.В. Рождественський ${ }^{11}$.

Для встановлення характеру багаторічних коливань максимальних витрат води і шарів стоку водопілля, крім трендів у часових рядах, розглянуто також різницеві інтегральні криві. Побудовані різницеві інтегральні криві (рис. 6, 7) вказують на наявність циклічності в коливаннях стоку весняного водопілля річок досліджуваної території, а саме підвищення стоку до 40-х років минулого століття, стабілізацію його до 80-х років, а після стрімке зменшення до 2015 року. Можна дійти висновку, що на досліджуваній території спостерігається синхронність у коливаннях максимального стоку весняного водопілля.

Можна зробити висновок, що на території Причорноморської низовини часові ряди максимальних витрат води та шарів стоку весняного водопілля $є$ убутними, переважно неоднорідними, за циклічністю коливань $є$ синхронними, мають маловодну фазу 3 кінця минулого сторіччя до 2015 року.

Такі висновки підтверджує більшість результатів досліджень авторів $^{12,13,14}$, які пов'язують зменшення весняного стоку для більшості рівнинних річок України з природними циклами водності та впливом змін клімату на водність річок.

11 Методические рекомендации по оценке однородности гидрологических характеристик и определению их расчетных значений по неоднородным данным. ГУ «ГГИ». 2010. С. 39-40.

${ }^{12}$ Горбачова Л.О., Барандіч С.Л. Просторово-часова мінливість максимального стоку води весняного водопілля та паводків змішаного походження річок України. Наукові праці Украӥнського науково-дослідного гідрометеорологічного інституту. 2016. Вип. 269. С. 107-114.

${ }^{13}$ Гребінь В.В., Ободовський О.Г., Жовнір В.В., Мудра К.В., Почаєвець О.О. Оцінювання однорідності рядів стокових характеристик річок районів річкових басейнів та суббасейнів України. Гідрологія, гідрохімія $і$ гідроекологія. 2019. № 1 (52). С. 36-50.

${ }^{14}$ Гопченко Є.Д., Овчарук В.А., Шакірзанова Ж.Р. Зміни гідрометеорологічних характеристик весняного водопілля на рівнинних річках України. Украӥнський гідрометеорологічний журнал. 2012. № 10 . С. 133-142. URL: http://nbuv.gov.ua/UJRN/Uggj_2012_10_18. 


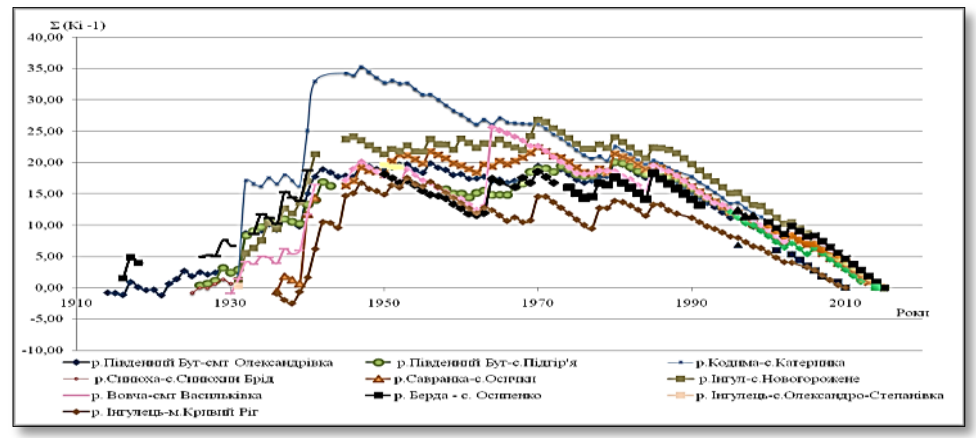

Рис. 6. Різницеві інтегральні криві максимальних витрат води весняного водопілля річок Причорномор'я

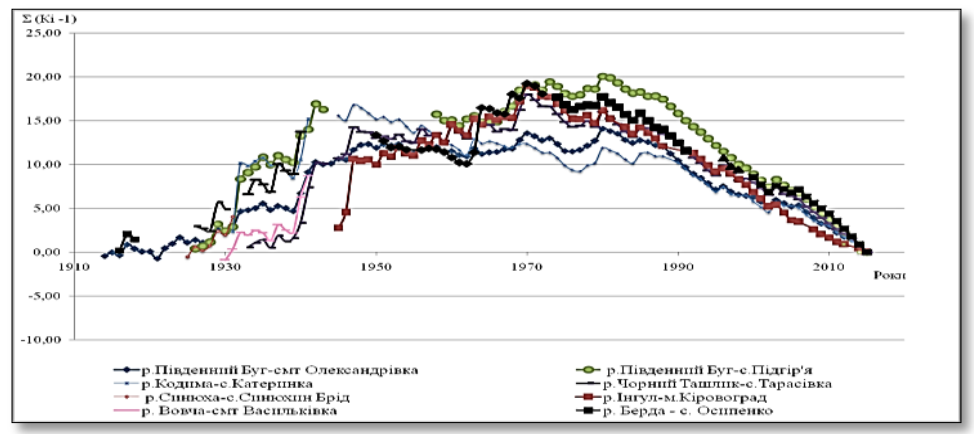

Рис. 7. Різницеві інтегральні криві шарів стоку весняного водопілля річок Причорномор'я

\section{2. Статистична обробка часових рядів шарів сток}

\section{та максимальних витрат води річок Причорноморської низовини}

За статистичного оброблення гідрологічних рядів стокових спостережень використовуються методи розрахунку оцінок параметрів розподілу, які можна умовно розділити на такі три групи ${ }^{15}$ : аналітичні, графоаналітичні і графічні.

Графічні і графоаналітичні методи поєднують елементи аналітичного розрахунку і графічної побудови. В аналітичних методах оцінки параметрів розподілу $\epsilon$ числами, отриманими шляхом підстановки вибіркових значень $x_{1}, x_{2}, \ldots, x_{n}$ випадкової величини $X$ уу

15 Рождественский А.В., Чеботарев А.И. Статистические методы в гидрологии. Ленинград : Гидрометеоиздат, 1974. 423 с. 
теоретичну формулу параметра, що визначається. При цьому бажано, щоб оцінка задовольняла вимогам незміщеності й ефективності ${ }^{16,17}$. До аналітичних методів належать методи моментів та найбільшої правдоподібності.

За наявними рядами максимальних витрат води та шарів стоку весняного водопілля розраховано параметри статистичного розподілу за методом моментів та найбільшої правдоподібності, такі як середнє арифметичне значення $\bar{x}$, коефіцієнт автокореляції $r(1)$, коефіцієнти варіації $C_{v}$ і асиметрії $C_{s}, C_{s} / C_{v}$.

Виконано просторовий аналіз характерних (середніх, мінімальних, максимальних) значень статистичних характеристик у межах річкових басейнів, які розташовані на території Причорноморської низовини, виділених за гідрографічним районуванням відповідно до вимог ВРД ЄС. Так, для максимальних витрат води весняного водопілля характерні значення часових рядів, осереднених у межах басейнів, виділених за гідрографічним районуванням, представлені в табл. 3.

Таблиця 3

Характерні величини параметрів $C_{v}, C_{s}$ і $C_{s} / C_{v}$ часових рядів максимальних витрат води весняного водопілля в межах басейнів на території Причорноморської низовини

\begin{tabular}{|c|c|c|c|c|c|c|c|c|c|}
\hline \multirow[t]{2}{*}{ № } & \multirow[t]{2}{*}{$\begin{array}{c}\text { Басейн } \\
\text { (субббасейн) }\end{array}$} & \multirow[t]{2}{*}{$\begin{array}{c}\text { Характерні } \\
\text { величини }\end{array}$} & \multicolumn{4}{|c|}{ Метод моментів } & \multicolumn{3}{|c|}{$\begin{array}{c}\text { Метод } \\
\text { найбільшої } \\
\text { правдоподібності }\end{array}$} \\
\hline & & & $r(1)$ & $C_{v}$ & $C_{s}$ & $\boldsymbol{C}_{s /} \boldsymbol{C}_{v}$ & $C_{v}$ & $C_{s}$ & $C_{s} C_{v}$ \\
\hline \multirow{3}{*}{1} & \multirow{3}{*}{$\begin{array}{c}\text { Басейн річок } \\
\text { Причорномор'я } \\
\text { (на прикладі } \\
\text { р. Тилігул) }\end{array}$} & Cep & 0,02 & 1,34 & 2,16 & 1,65 & 1,40 & 2,88 & 2,15 \\
\hline & & Міні & & 1,2 & 2,04 & 1,4 & 1,26 & 2,52 & 1,7 \\
\hline & & Максимальні & & 1,46 & 2,27 & 1,9 & 1,54 & 3,24 & 2,6 \\
\hline \multirow{3}{*}{2} & \multirow{3}{*}{$\begin{array}{c}\text { Басейн річок } \\
\text { Південного } \\
\text { Бугу }\end{array}$} & $\mathrm{Ce}$ & 0,21 & 1,39 & 2,54 & 1,48 & 1,44 & 3,33 & 2,3 \\
\hline & & Мінімальні & & 1,07 & 1,43 & 1,3 & 1,08 & 1,67 & 1,4 \\
\hline & & Максимальні & & 2,29 & 4,95 & 3,00 & 2,40 & 7,49 & 4,3 \\
\hline \multirow{3}{*}{3} & \multirow{3}{*}{$\begin{array}{c}\text { Суббасейн } \\
\text { Нижнього } \\
\text { Дніпра }\end{array}$} & Cep & 0,24 & 1,59 & 2,71 & 1,6 & 1,66 & 3,78 & 2,2 \\
\hline & & Мінімальні & & 1,08 & 1,40 & 1,1 & 1,11 & 1,81 & 1,5 \\
\hline & & Максимальні & & 2,61 & 4,93 & 2,3 & 2,78 & 7,75 & 3,2 \\
\hline \multirow{3}{*}{4} & \multirow{3}{*}{$\begin{array}{c}\text { Басейн річок } \\
\text { Приазов'я }\end{array}$} & Середні & 0,13 & 2,02 & 3,59 & 1,70 & 2,15 & 5,94 & 2,6 \\
\hline & & Мінімальні & & 1,54 & 2,12 & 1,3 & 1,58 & 2,50 & 1,6 \\
\hline & & Максимальні & & 3,01 & 6,06 & 2,0 & 3,36 & 13,4 & 4,0 \\
\hline
\end{tabular}

1) Для річок Причорномор'я (на прикладі p. Тилігул) для максимальних витрат води за методом найбільшої правдоподібності

${ }^{16}$ Гопченко Є.Д., Гушля О.В. Гідрологія суші 3 основами водних меліорацій : навчальний посібник. Київ : ІСЛЮ, 1994. 296 с.

${ }^{17}$ Соколовский Д.Л. Речной сток. Ленинград : Гидрометеоиздат, 1968, 532 с. 
отримано таке: середне значення $C_{v}$ становить 1,40 , середнє співвідношення $C_{s} / C_{v}$ становить 2,15 при коефіцієнті автокореляції 0,02.

2) Для річок у межах басейну Південного Бугу для максимальних витрат води за методом найбільшої правдоподібності отримано таке: середнє значення $C_{v}$ становить 1,44 , середнє співвідношення $C_{s} / C_{v}$ становить 2,30 при коефіцієнті автокореляції 0,21.

3) Для суббасейну нижнього Дніпра для максимальних витрат води за методом найбільшої правдоподібності отримано таке: середнє значення $C_{v}$ становить 1,66 , середнє співвідношення $C_{s} / C_{v}$ становить 2,20 при коефіцієнті автокореляції 0,24.

4) Для річок Приазов'я для максимальних витрат води за методом найбільшої правдоподібності отримано таке: середнє значення $C_{v}$ становить 2,15 , середнє співвідношення $C_{s} / C_{v}$ становить 2,60 при коефіцієнті автокореляції 0,13 .

Територіальний розподіл середніх значень статистичних характеристик максимальних витрат води весняного водопілля в межах басейнів річок Причорноморської низовини представлений на рис. 8. Загалом спостерігається збільшення коефіцієнта варіації $C_{v}$ iз заходу на схід території від 1,40-1,44 у басейнах річок Причорномор'я та річки Південний Буг до 1,66 у суббасейні Нижнього Дніпра та 2,15 у басейнах річок Приазов'я. В такому ж напрямі збільшується співвідношення $C_{s} / C_{v}$, а саме від 2,15 до 2,60.

Для шарів стоку весняного водопілля характерні значення часових рядів, осереднених у межах басейнів, виділених за гідрографічним районуванням, представлені в табл. 4.

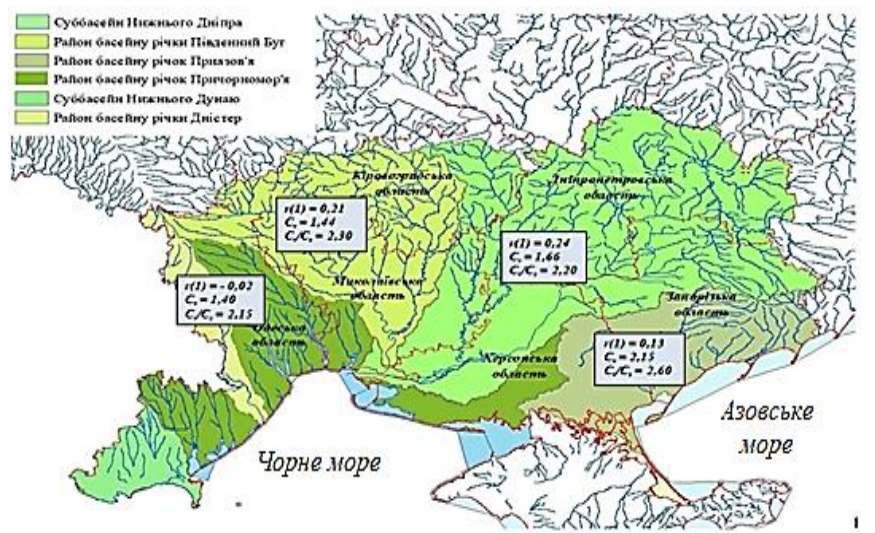

Рис. 8. Розподіл середніх значень статистичних характеристик максимальних витрат води весняного водопілля в межах басейнів на території Причорноморської низовини 
Таблиця 4

Характерні величини параметрів $C_{v}, C_{s}$ i $C_{s} / C_{v}$ часових рядів шарів стоку весняного водопілля в межах басейнів

на території Причорноморської низовини

\begin{tabular}{|c|c|c|c|c|c|c|c|c|c|}
\hline \multirow[t]{2}{*}{ № } & \multirow{2}{*}{$\begin{array}{c}\text { Басейн } \\
\text { (суббасейн) }\end{array}$} & \multirow{2}{*}{$\begin{array}{c}\text { Характерні } \\
\text { величини }\end{array}$} & \multicolumn{4}{|c|}{ Метод моментів } & \multicolumn{3}{|c|}{$\begin{array}{l}\text { Метод найбільшої } \\
\text { правдоподібності }\end{array}$} \\
\hline & & & $r(1)$ & $C_{v}$ & $C_{s}$ & $C_{s /} C_{v}$ & $C_{v}$ & $C_{s}$ & $C_{s} C_{v}$ \\
\hline \multirow{3}{*}{1} & \multirow{3}{*}{$\begin{array}{c}\text { Басейн річок } \\
\text { Причорномор'я } \\
\text { (на прикладі } \\
\text { р. Тилігул) }\end{array}$} & Середні & 0,03 & 1,17 & 2,58 & 2,25 & 1,2 & 3,62 & 3,05 \\
\hline & & Мінімальні & & 0,94 & 2,24 & 2,10 & 0,96 & 3,19 & 2,80 \\
\hline & & Максимальні & & 1,40 & 2,92 & 2,40 & 1,44 & 4,04 & 3,30 \\
\hline \multirow{3}{*}{2} & \multirow{3}{*}{$\begin{array}{c}\text { Басейн річок } \\
\text { Південного } \\
\text { Бугу } \\
\end{array}$} & Середні & 0,20 & 0,99 & 2,07 & 2,09 & 1,02 & 2,62 & 2,55 \\
\hline & & Мінімальні & & 0,68 & 1,23 & 1,30 & 0,68 & 1,28 & 1,60 \\
\hline & & Максимальні & & 1,23 & 4,08 & 3,70 & 1,29 & 5,72 & 5,00 \\
\hline \multirow{3}{*}{3} & \multirow{3}{*}{$\begin{array}{c}\text { Суббасейн } \\
\text { Нижнього } \\
\text { Дніпра } \\
\end{array}$} & Середні & 0,14 & 1,08 & 1,89 & 1,74 & 1,11 & 2,39 & 2,16 \\
\hline & & Мінімальні & & 0,78 & 0,87 & 1,00 & 0,82 & 0,96 & 1,10 \\
\hline & & Максимальні & & 1,38 & 3,56 & 3,10 & 1,42 & 5,06 & 4,20 \\
\hline \multirow{3}{*}{4} & \multirow{3}{*}{$\begin{array}{c}\text { Басейн річок } \\
\text { Приазов'я }\end{array}$} & Середні & 0,19 & 1,20 & 3,04 & 2,54 & 1,27 & 4,55 & 3,56 \\
\hline & & Мінімальні & & 0,98 & 2,25 & 1,90 & 1,00 & 2,88 & 2,30 \\
\hline & & Максимальні & & 1,39 & 4,59 & 3,50 & 1,49 & 8,71 & 5,90 \\
\hline
\end{tabular}

1) Для річок Причорномор'я (на прикладі р. Тилігул) для шарів стоку за методом найбільшої правдоподібності отримано таке: середні значення $C_{v}$ становить 1,20 , середнє співвідношення $C_{s} / C_{v}$ становить 3,05 при коефіцієнті автокореляції 0,03.

2) Для річок у межах басейну Південного Бугу для шарів стоку за методом найбільшої правдоподібності отримано таке: середнє значення $C_{v}$ становить 1,02 , середнє співвідношення $C_{s} / C_{v}$ становить 2,55 при коефіцієнті автокореляції 0,20.

3) Для суббасейну нижнього Дніпра для шарів стоку за методом найбільшої правдоподібності отримано таке: середнє значення $C_{v}$ становить 1,11 , середне співвідношення $C_{s} / C_{v}$ становить 2,16 при коефіцієнті автокореляції 0,14.

4) Для річок Приазов'я для шарів стоку за методом найбільшої правдоподібності отримано таке: середнє значення $C_{v}$ становить 1,27, середнє співвідношення $C_{s} / C_{v}$ становить 3,56 при коефіцієнті автокореляції 0,19.

Територіальний розподіл середніх значень статистичних характеристик шарів стоку весняного водопілля в межах басейнів на території Причорноморської низовини представлений на рис. 9. Загалом коефіцієнт варіації $C_{v}$ та співвідношення $C_{s} / C_{v}$ мають більші значення для басейнів півдня території (річки Причорномор'я та Приазов'я): $C_{v}$ на рівні $1,20-1,27$ та $C_{s} / C_{v}$ на рівні $3,05-3,56$ відповідно. Значення дещо зменшуються на північ: коефіцієнт варіації $C_{v}$ становить 
$1,02-1,11$, співвідношення $C_{s} / C_{v}$ становить $2,16-2,55$ (річка Південний Буг та річки суббасейну Нижнього Дніпра).

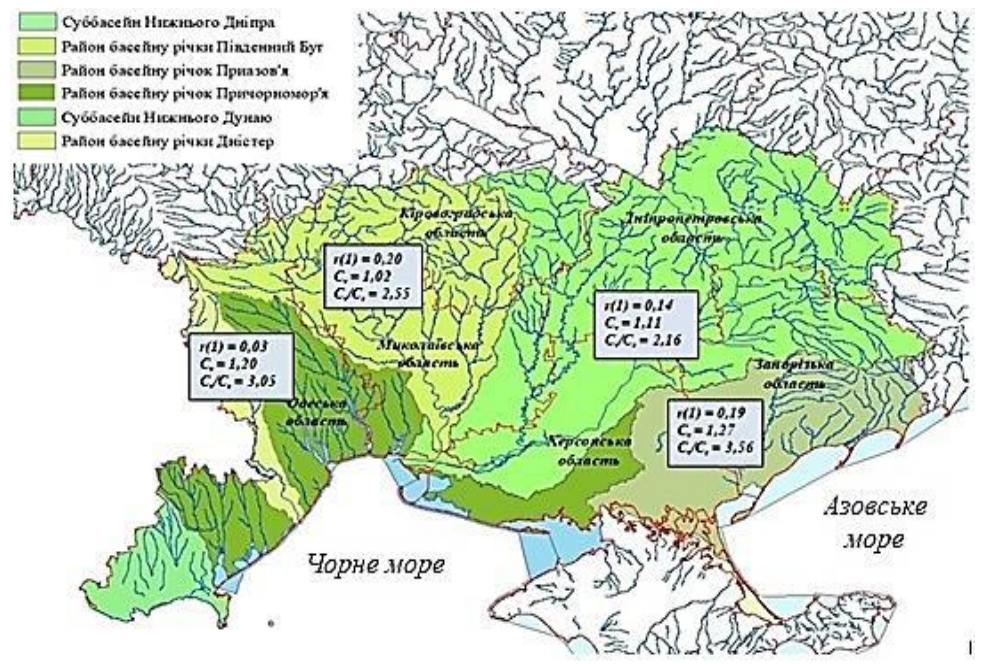

Рис. 9. Розподіл середніх значень статистичних характеристик шарів стоку весняного водопілля в межах басейнів на території Причорноморської низовини

\section{ВИСНОВКИ}

В результаті просторово-часового аналізу характеристик максимального стоку весняного водопілля річок Причорноморської низовини отримано такі основні висновки.

1) Хронологічні графіки максимальних витрат води та шарів стоку весняних водопіль вказують на те, що спостерігається багаторічна тенденція до суттєвого зменшення досліджуваних величин. Більшість рядів максимального стоку весняного водопілля неоднорідна зі значущими трендами.

2) Різницеві інтегральні криві для максимальних витрат води та шарів стоку весняних водопіль вказують на наявність циклічності в коливаннях стоку весняного водопілля річок досліджуваної території 3 маловодною фазою з кінця минулого сторіччя до 2015 року.

3) В результаті аналізу просторового розподілу статистичних параметрів максимальних витрат води та шарів стоку весняного водопілля виконано їх осереднення в межах басейнів на досліджуваній території. При цьому встановлено, що одержані за методом найбільшої 
правдоподібності статистичні параметри максимальних витрат та шарів стоку змінюються таким чином:

- для максимальних витрат води спостерігається збільшення коефіцієнта варіації $C_{v}$ у напрямку із заходу на схід від $1,40-1,44$ (в басейнах річок Причорномор'я та річки Південний Буг) до 1,66 (в суббасейні Нижнього Дніпра) та 2,15 (в басейнах річок Приазов'я); в такому ж напрямку збільшується співвідношення $C_{s} / C_{v}$ : від 2,15 до 2,60 ;

- для шарів стоку весняного водопілля коефіцієнт варіації $C_{v}$ і співвідношення $C_{s} / C_{v}$ мають більші значення для басейнів півдня території, становлячи 1,20-1,27 та 3,05-3,56 відповідно (річки Причорномор'я та Приазов'я); їх значення дещо зменшуються на північ: коефіцієнт варіації становить $1,02-1,11$, а співвідношення $C_{s} / C_{v}$ становить 2,16-2,55 (річка Південний Буг та річки суббасейну Нижнього Дніпра).

\section{АНОТАЦІЯ}

В дослідженні представлено результати просторово-часового аналізу максимального стоку весняного водопілля на неоднорідній за фізико-географічними характеристиками території Причорноморської низовини. Актуальність роботи обумовлена тим, що саме весняне водопілля $\epsilon$ найбільш характерною багатоводною фазою досліджуваної території, об'єми стоку якої на невеликих річках півдня сягають 60-70\% від річного. У багатоводні роки весняне водопілля супроводжується підйомом рівнів води, затопленням територій, руйнацією господарських об'єктів. Під час використання сучасних вихідних даних виконано дослідження часових рядів максимального стоку весняних водопіль на території Причорноморської низовини, а саме побудовані хронологічні графіки, що вказують на те, що спостерігається тенденція до суттєвого зменшення досліджуваних величин; побудовані різницеві інтегральні криві, що доводять наявність циклічності в коливаннях стоку весняного водопілля; проведено оцінювання значущості лінійних трендів часових рядів; визначені основні статистичні характеристики, які були осереднені та узагальнені в межах басейнів річок досліджуваної території.

\section{ЛIТЕРАТУРА}

1. Физико-географическое районирование Украинской УССР. Киев : изд-во КГУ, 1968. 683 с.

2. Ресурсы поверхностных вод СССР. Т. 6 : Украина и Молдавия. Вып. 1 : Западная Украина и Молдавия / под ред. М.С. Каганера. Ленинград : Гидрометеоиздат, 1969. 884 с. 
3. Гребінь В.В. Сучасний водний режим річок України (ландшафтно-гідрологічний аналіз). Київ : Ніка-Центр, 2010. 316 с.

4. Водна Рамкова Директива Свропейського Союзу 2000/60/СС. Основні терміни та їх визначення. Київ, 2006. 240 с.

5. Гребінь В.В., Яцюк М.В., Чунарьов О.В. Гідрографічне районування території України як передумова розробки планів інтегрованого управління річковими басейнами. Гідрологія, гідрохімія $i$ гідроекологія. 2012. Т. 2 (27). С. 8-16.

6. Методики гідрографічного та водогосподарського районування території України відповідно до вимог Водної Рамкової Директиви Європейського Союзу / В.В. Гребінь, В.Б. Мокін, В.А. Сташук, В.К. Хільчевський, М.В. Яцюк, О.В. Чунарьов, С.М. Крижановський, В.С. Бабчук, О.С. Ярошевич. Київ : Інтерпрес ЛТД, 2013. 55 с.

7. World Meteorological Organization. Guide to Hydrological Practices, Fifth Edition, TD No. 168, 1994.

8. Методические рекомендации по оценке однородности гидрологических характеристик и определению их расчетных значений по неоднородным данным. Санкт-Петербург, 2010. 162 с.

9. Рождественский А.В. Оценка точности кривых распределения гидрологических характеристик. Ленинград : Гидрометеоиздат, 1977. $260 \mathrm{c}$.

10. Смельянова К.Б., Докус А.О. Дослідження часових рядів характеристик весняного стоку річок території Причорноморської низовини. Екологія, неоекологія, охорона навколишнього середовища та збалансоване природокористування : матеріали VIII Міжнародної наукової конференції молодих вчених (26-27 листопада 2020 року, м. Харків). 2020.

11. Методические рекомендации по оценке однородности гидрологических характеристик и определению их расчетных значений по неоднородным данным. ГУ «ГГИ». 2010. С. 39-40.

12. Горбачова Л.О., Барандіч С.Л. Просторово-часова мінливість максимального стоку води весняного водопілля та паводків змішаного походження річок України. Наукові праці Українського науково-дослідного гідрометеорологічного інституту. 2016. Вип. 269. C. $107-114$.

13. Гребінь В.В., Ободовський О.Г., Жовнір В.В., Мудра К.В., Почаєвець О.О. Оцінювання однорідності рядів стокових характеристик річок районів річкових басейнів та суббасейнів України. Гідрологія, гідрохімія і гідроекологія. 2019. № 1 (52). С. 36-50.

14.Гопченко Є.Д., Овчарук В.А., Шакірзанова Ж.Р. Зміни гідрометеорологічних характеристик весняного водопілля на рівнинних 
річках України. Український гідрометеорологічний журнал. 2012. № 10. C. 133-142. URL: http://nbuv.gov.ua/UJRN/Uggj_2012_10_18.

15. Рождественский А.В., Чеботарев А.И. Статистические методы в гидрологии. Ленинград : Гидрометеоиздат, 1974. 423 с.

16. Гопченко Є.Д., Гушля О.В. Гідрологія суші з основами водних меліорацій : навчальний посібник. Київ : ІСЛЮ, 1994. 296 с.

17. Соколовский Д.Л., Речной сток. Ленинград : Гидрометеоиздат, 1968. $532 \mathrm{c}$.

\section{Information about the authors:} Shakirzanova Zh. R., Doctor of Science (Habilitat) in Geography, Professor, Head of the Department of Land Hydrology Odesa State Environmental University 15, Lvivska str., Odesa, 65016, Ukraine

Yemelianova K. B., $\mathrm{PhD}$ Student at the Department of Land Hydrology Odesa State Environmental University 15, Lvivska str., Odesa, 65016, Ukraine 